\title{
Article
}

http://dx.doi.org/10.11646/phytotaxa.174.3.1

\section{Two new species of Dendrobium (Orchidaceae: Epidendroideae) from China: evidence from morphology and DNA}

\author{
QING XU1,2, GUO-QIANG ZHANG ${ }^{3}$, ZHONG-JIAN LIU ${ }^{3} \&$ YI-BO LUO ${ }^{1}$ \\ ${ }^{1}$ State Key Laboratory of Systematic and Evolutionary Botany, Institute of Botany, Chinese Academy of Sciences, Beijing 100093, China; \\ E-mail:luoyb@ibcas.ac.cn \\ ${ }^{2}$ University of Chinese Academy of Sciences, Beijing 100049, China \\ ${ }^{3}$ Shenzhen Key Laboratory for Orchid Conservation and Utilization, The National Orchid Conservation Center of China and The Orchid \\ Conservation and Research Center of Shenzhen, Shenzhen, 518114, China
}

\begin{abstract}
Two new orchid species, Dendrobium wenshanense and D. longlingense, from Yunnan, China, are described and illustrated in this study based on morphological and molecular evidence. Morphological analysis indicates that D. wenshanense is similar to $D$. wilsonii and $D$. fanjingshanense, but they differ in floral color, length of column foot and shapes/sizes of sepals, petals and lip; D. longlingense is similar to D. longicornu, but differs in presence of black hairs on adaxial surface of leaf, position of inflorescences, floral color and shapes of lip and spur. Molecular analysis of combined nuclear and plastid datasets (ITS, matK, $r b c L, t r n H$ - $p s b A, t r n L$ intron) reveals that $D$. wenshanense is sister to $D$. wilsonii and $D$. fanjingshanense and a member of section Dendrobium; D. longlingense is sister to D. longicornu and a member of section Formosae.
\end{abstract}

Key words: Chinese orchid flora, Dendrobium sect. Dendrobium, Dendrobium sect. Formosae, molecular phylogenetics of Dendrobium

\section{Introduction}

The genus Dendrobium Swartz (1799: 82; Orchidaceae: Epidendroideae), with more than 1100 species, is one of the largest genera in Orchidaceae. It is widely distributed in India, Japan, Malaysia, Indonesia, Australia and New Guinea, with some species extending to the Pacific islands (Wood, 2006). Some 80 species are found in China, of which 14 are endemic (Zhu et al., 2009). The genus is characterized by lateral inflorescences, lateral sepals adnate to elongate column foot and part of lip to form a mentum and four naked pollinia. Lindley (1844) proposed four sections initially, later expanded to ten (1851). Schlechter (1912) recognised four subgenera and 41 sections. Recently, Clements et al. (2002, 2003, 2006) divided the broad genus Dendrobium into three subtribes, but Schuiteman (2011) proposed a broad circumscription of Dendrobium including the other genera of the subtribe Dendrobiinae.

Given the widely varying habitats, large number of species and diverse morphologies, the taxonomy of this genus is complicated, and many species have not been found since they were originally described. Recently, during our fieldwork in Yunnan, two new species were discovered. After careful observation of transplanted individuals in The National Orchid Conservation Center of China (NOCC), morphological studies and literature comparison of similar Dendrobium species, molecular phylogenetic analysis was conducted to determine their phylogenetic positions. The morphological analyses indicated that they are new species of Dendrobium, and the molecular analyses placed one in section Dendrobium and the other in section Formosae.

\section{Materials and methods}

Macromorphology and micromorphology observation:-Gross morphological data were obtained during fieldwork, and specimens were deposited in the herbarium of NOCC. Measurements, shapes, colours and other details given in the description are based on living material. Pollinia were taken from fully opened flowers, and the micromorphological observations were conducted under a Guiguang XTL-500 microscope. 
Conservation status:- Using the World Conservation Union Red List Categories and Criteria (IUCN, 2001), D. longlingense should be treated as critically endangered.

Species recognition:-Dendrobium longlingense is distinct among species in the genus because it has dense black hairs on leaf abxial surface and leaf sheaths, subterminal inflorescences arising from leafless stems, and a golden yellow lip slightly curved to form spur. The lip is subflabellate with a sharp tooth at the apex of midlobe and a disk with one thick, fleshy longitudinal ridge. It is morphologically similar to $D$. longicornu, but can be easily distinguished from the latter, which has blackish brown rigid hairs on both leaf surfaces and leaf sheaths and subterminal inflorescences on leafy stems. The lip is subobovate or rhombic. The central part of the disk is orange with 3 or 4 keeled longitudinal ridges. The mentum is straight and forms a spur.

\section{Acknowledgment}

We thank Xue-Yong Ma and Pei-Wen Zhang for the illustrations presented in this study, Li-Jun Chen and Wen-Hui Rao for image preparation, and Liu-Yin Chen for molecular analyses. Two anonymous reviewers provided helpful comments and suggestions.

\section{References}

Clements, M.A. \& Jones, D.L. (2002) Nomenclatural changes in the Dendrobieae (Orchidaceae) 1: the Australasian region. Orchadian 13: 485-497.

Clements, M.A. (2003) Molecular phylogenetic systematics in the Dendrobiinae (Orchidaceae), with emphasis on Dendrobium section Pedilonum. Telopea 10: 247-298.

Clements, M.A. (2006) Molecular phylogenetic systematics in Dendrobieae (Orchidaceae). Aliso 22: 465-480.

Doyle, J.J. \& Doyle, J.L. (1987) A rapid isolation procedure from small quantities of fresh leaf tissue. Phytochem Bull 19: 11-15.

IUCN (2001) IUCN red list categories and criteria, version 3.1. Gland, IUCN Species Survival Commission.

Lindley, J. \& Paxton, J. (1851) The transparent dendrobe. Paxton's Flower Garden 1: 133-136.

http://dx.doi.org/10.1017/cbo9781139095648.028

Lindley, J. (1844) Dendrobium. Botanical Register 30: 46-64.

Liu, Z.J., Chen, L.J., Chen, S.C., Cai, J., Tsai, W.C., Hsiao, Y.Y., Ma, X.Y. \& Zhang, G.Q. (2011) Paraholcoglossum and Tsiorchis, two new orchid genera established by molecular and morphological analyses of the Holcoglossum alliance. PLoS ONE 6: e24864. http://dx.doi.org/10.1371/journal.pone.0024864

Mike, T., Lena, S. \& Joachim, W.K. (1999) The phylogenetic relationships and evolution of the Canarian laurel forest endemic Ixanthus viscosus (Aiton) Griseb. (Gentianaceae): evidence from $m a t K$ and ITS sequences, and floral morphology and anatomy. Plant Systematics Evolution 218: 299-317. http://dx.doi.org/10.1007/bf01089233

Reeves, G., Chase, M.W., Goldblatt, P., Rudall, P., Fay, M.F., Cox, A.V., Lejeune, B. \& Souza-Chies, T. (2001) Molecular systematics of Iridaceae: evidence from four plastid DNA regions. American Journal of Botany 88: 2074-2087. http://dx.doi.org/10.2307/3558433

Sang, T., Crawford, D.J., Stuessy, T.F. (1997) Chloroplast DNA phylogeny, reticulate evolution, and biogeography of Paeonia (Paeoniaceae). American Journal of Botany 84: 1120-1136. http://dx.doi.org/10.2307/2446155

Schlechter, R. (1912) Die Orchidaceen von Deutsch-Neu-Guinea. In: Fedde, F. (Eds.) Repertorium Specierum Novarum Regni Vegetabilis. Beihefte Band 1. Koeltz, Berlin, Germany.

Schuiteman, A. (2011) Dendrobium (Orchidaceae): to split or not to split? Gardens'Bulletin Singapore 63: 245-257.

Sulaiman, S.F., Culham, A. \& Harborne J.B. (2003) Molecular phylogeny of Fabaceae based on $r b c L$ sequence data: with special emphasis on the tribe Mimoseae (Mimosoideae). Asia Pacific Journal of Molecular Biology and Biotechnology 11: 9-35.

Swartz, O. (1799) Dendrobium. Nova Acta Regiae Societatis Scientiarum Upsaliensis 6: 82-85.

Taberlet, P., Gielly, L., Pautou, G. \& Bouvet, J. (1991) Universal primers for amplification of three non-coding regions of chloroplast DNA. Plant Molecular Biology 17: 1105-1109. http://dx.doi.org/10.1007/bf00037152

Wood, H.P. (2006) The dendrobiums. Gantner, Ruggell, pp. 3-10. 
Xiang, X.G., Schuiteman, A., Li, D.Z., Huang, W.C., Chung, S.W., Li, J.W., Zhou, H.L., Jin, W.T., Lai, Y.J., Li, Z.Y. \& Jin, X.H. (2013) Molecular systematics of Dendrobium (Orchidaceae, Dendrobieae) from mainland Asia based on plastid and nuclear sequences. Molecular Phylogenetics and Evolution 65: 950-960.

http://dx.doi.org/10.1016/j.ympev.2013.06.009

Zhang, G.Q., Liu, K.W., Chen, L.J., Xiao, X.J., Zhai, J.W., Li, L.Q., Cai, J., Hsiao, Y.Y., Rao, W.H. Huang, J., Ma, X.Y., Chung, S.W., Huang, L.Q., Tsai, W.C. \& Liu, Z.J. (2013) A new molecular phylogeny and a new genus, Pendulorchis, of the Aerides-Vanda alliance (Orchidaceae: Epidendroideae). PloS One 8: e60097.

http://dx.doi.org/10.1371/journal.pone.0060097

Zhu, G.H., Ji, Z.H., Wood, J.J. \& Wood, H.P. (2009) Dendrobium. In: Wu, C.Y., Raven, P.H. \& Hong, D.Y. (Eds.) Flora of China. Scientific Press, Beijing, pp. 367-397. 